Article

\title{
The Vulnerability of Coastal Tourism Destinations to Climate Change: The Usefulness of Policy Analysis
}

\author{
Raquel Santos-Lacueva * (D), Salvador Anton Clavé and Òscar Saladié \\ Research Group on Territorial Analysis and Tourism Studies (GRATET), Department of Geography, \\ Rovira i Virgili University, 43480 Vila-seca, Spain; salvador.anton@urv.cat (S.A.C.); oscar.saladie@urv.cat (Ò.S.) \\ * Correspondence: raquel.santos@urv.cat; Tel.: +34-977-297-900
}

Received: 4 August 2017; Accepted: 7 November 2017; Published: 9 November 2017

\begin{abstract}
Climate change conditions the sustainability of coastal destinations. This paper looks at the physical conditions that determine exposure and sensitivity to and risk from climate change and explores the sociopolitical contextual factors that determine the vulnerability of destinations. We define a destination's vulnerability to climate change as being a reduction in its attractiveness caused by climate change combined with the consequences of adaptation and mitigation strategies. To be more specific, this paper aims to discuss the linkage between policymaking and the vulnerability of coastal destinations to climate change. We look at how this vulnerability is determined by decision-making, policies and strategies and propose an innovative analytical framework to assess vulnerability using a policy analysis approach. It is our intention to combine a content analysis of policy documents with an analysis of the perceptions and opinions of the stakeholders that influence decision-making. The paper deals with the complex, multiple, dynamic and fuzzy attributes that characterize all the items that make up this kind of research: climate change (phenomenon), vulnerability (variable), policy analysis (method), policy contents and stakeholder perceptions (indicators), coastal destinations (territorial system) and tourism (activity and policy).
\end{abstract}

Keywords: vulnerability; climate change; policy analysis; coastal tourism; sustainable tourism planning

\section{Introduction}

Vulnerability is an attractive concept within which to frame research into global change because it encompasses interdependent systems both human and natural; it enables a link to be made between these two different dimensions; and it makes it possible to forecast impacts. However, these advantages also make methodologies and research more complicated [1].

Vulnerability is the noun from the adjective "vulnerable" and has negative connotations. To be vulnerable is to be exposed to the possibility of being damaged or badly influenced. Adverse impacts are only potential since they may or may not actually happen, and threats are analyzed by means of future projections and scenarios. Theory on vulnerability covers not only climate change but also a variety of fields such as risk management, famine, public health and security.

In practice, academics use the term in numerous ways for different purposes. Thywissen [2] lists thirty-six definitions of vulnerability and illustrates the difficulty of capturing all dimensions of the concept, which change over time and on a geographical scale. Other scholars have proposed a number of frameworks, but all of them are different. There are other attempts to provide a standard approach suitable in practice for several sectors, terms and issues [3]. The definitions of vulnerability given by the Intergovernmental Panel on Climate Change (IPCC) also reflect scientific progress, but they are still too wide. For example, the last two definitions are:

"Vulnerability is the degree to which a system is susceptible to, and unable to cope with, adverse effects of climate change, including climate variability and extremes. Vulnerability is a function of 
the character, magnitude, and rate of climate change and variation to which a system is exposed, its sensitivity, and its adaptive capacity" [4].

"Vulnerability is the propensity or predisposition to be adversely affected. Vulnerability encompasses a variety of concepts including sensitivity or susceptibility to harm and lack of capacity to cope and adapt" [5].

Table 1 shows some examples of frameworks that differ not only on the scale and purposes of the vulnerability assessment, but also on the components that determine vulnerability. A common factor is the importance given to a function consisting of exposure, sensitivity and adaptive capacity [4].

Coastal tourism is highly dependent on natural resources [6], mainly climate [7,8], beaches and sea. In fact, tourism has to deal with the "environmental paradox" [9] because sustainability and competitiveness of destinations depend on conservation of natural resources, while, at the same time, tourism activity stress those resources, especially on the coast. Moreover, environmental resources are mostly common goods, such as beaches, that governments have to manage considering a variety of stakeholders' interests. Climate change is expected to modify, among other things, the spatial and temporal distribution of comfortable temperatures, the availability of beaches for recreation and the quality of marine ecosystems $[10,11]$. It is not only physical features but also human decisions and strategies that increase or reduce the vulnerability of tourism destinations.

The European Topic Centre on Climate Change Impacts, Vulnerability and Adaptation (ETC/CCA) [12] analyses the advantages and disadvantages of different ways of assessing coastal vulnerability to climate change. It differentiates between index-based methods (e.g., [13,14]), indicator-based approaches (e.g., [15]), GIS-based decision support systems (e.g., [16]) and methods based on dynamic computer models (e.g., [17]). The review reveals obstacles in connection with dataset availability and regional disaggregation, a lack of accurate indicators, the length of time needed for implementation and difficulties in dealing with social and natural systems together. Assessments of vulnerability to climate change specifically in coastal destinations also comprise a wide range of scales, purposes, indicators and methods. There is no consensus on how to evaluate vulnerability. Table 2 shows some examples of assessments around the world.

Research based on vulnerability therefore involves a number of challenges. To improve the usefulness of the concept, synergies with other terms (e.g., risk, hazards, sustainability, adaptation, sensitivity, exposure, mitigation, stressors, and resilience) need to be incorporated [18,19]. These concepts are also used and defined in numerous ways. We use them here in the same way as the IPCC did in its last report [5].

Moreover, it is important to enhance integrated methodologies that can combine socioecological systems and incorporate non-climate stressors [20]. We also need to include perceptions of risk and governance studies, since the involvement of stakeholders and attention on a local scale are the keys to successful assessment [21-23]. In addition, it is important to incorporate values-based approaches which are related to decision-making and responses to climate change [24,25]. Finally, there is a need to go beyond studies that focus mainly on physical conditions [26], are conducted on a national scale (e.g., [27]) or rank territories according to a numerical index, because they do not indicate specific local circumstances. Vulnerability is specific to a given location [28], so data and adaptation need to be adjusted locally [29]. Thus, generalizing from too large a scale leads to explanations that may not be precise enough when it comes to improving decision-making and guaranteeing the sustainability of tourism activity locally. 
Table 1. Examples of vulnerability frameworks.

\begin{tabular}{|c|c|}
\hline Framework & Components \\
\hline $\begin{array}{l}\text { Destination Sustainability Framework (DSF) } \\
\text { designed to assess destination vulnerability and } \\
\text { resilience (applicable not only to climate change) [30]. }\end{array}$ & $\begin{array}{l}\text { (1) Shock(s) or stressor(s). } \\
\text { (2) Interconnected dimensions of vulnerability: exposure, } \\
\text { sensitivity, and system adaptability. } \\
\text { (3) Dynamic feedback loops that express the multiple outcomes of } \\
\text { actions taken (or not). } \\
\text { (4) Contextualized root causes that shape destinations and } \\
\text { their characteristics. } \\
\text { (5) Various spatial scales. } \\
\text { (6) Multiple timeframes within which social-ecological } \\
\text { change occurs. }\end{array}$ \\
\hline
\end{tabular}

(1) Exposure (mean climate, extreme events, sea level rise,

Framework for the vulnerability of the tourism sector to climate change at national level [31]. biodiversity, water availability, snow, mitigation measures).

(2) Sensitivity (same variables as exposure).

(3) Adaptive capacity (economic resources, innovation potential, technology, knowledge, effectiveness of institutions).

(1) System analysis.

(2) Identification of activity and hazard sub-systems.

Five-step vulnerability assessment methodology for

(3) Vulnerability assessments for the different sub-systems at risk (using the Vulnerability Scoping Diagram [1]). tourism in coastal areas [21]

(4) Integration for the destination as a whole and scenario analysis.

(5) Communication.

(1) Timeframe: current vs. future vs. dynamic.

(2) Sphere: internal vs. external vs. cross-scale.

(3) Knowledge domain: socioeconomic vs. biophysical vs. integrated.

A general applicable conceptual framework for climate change research [22].

(4) Vulnerable system.

(5) Attribute of concern.

(6) Hazard.

(1) Hazard and associated outcome(s) of interest.

The Vulnerability Scoping Diagram (VSD) to facilitate

(2) Exposure unit (human-environment system). comparison between assessments [1].

(3) Dimensions (exposure, sensitivity and adaptive capacity).

(4) Components of each dimension.

(5) Measures of the components.

(1) Define study area together with stakeholders.

(2) Get to know place over time.

(3) Hypothesize who is vulnerable to what.

Eight-step approach to guide vulnerability assessments of coupled human-environment systems [23].
(4) Develop a causal model of vulnerability (exposure, sensitivity and adaptive capacity).

(5) Find indicators for the elements of vulnerability.

(6) Operationalize model(s) of vulnerability.

(7) Project future vulnerability.

(8) Communicate vulnerability creatively.

(1) Multiple interacting perturbations and stressors or stresses and their sequencing.

(2) Exposure beyond the presence of a perturbation and stressor or stress, including the manner in which the coupled system experiences hazards.

A framework for vulnerability analysis in sustainability science [18].
(3) Sensitivity of the coupled system to the exposure.

(4) The system's capacities to cope or respond (resilience), including the consequences and attendant risks of slow (or poor) recovery.

(5) The system's restructuring after the responses taken (i.e., adjustments or adaptations).

(6) Nested scales and scalar dynamics of hazards, coupled systems, and their responses. 
Table 2. Examples of assessments of vulnerability to climate change in coastal destinations.

\begin{tabular}{|c|c|c|c|}
\hline Case Study & What Is Assessed? & How Is It Assessed? & Vulnerability Determinants \\
\hline $\begin{array}{l}\text { Western Indian } \\
\text { Ocean countries [32] }\end{array}$ & $\begin{array}{l}\text { Vulnerability of coastal } \\
\text { communities to key } \\
\text { impacts of climate } \\
\text { change on coral } \\
\text { reef fisheries. }\end{array}$ & $\begin{array}{l}29 \text { communities' assessment } \\
\text { through models (exposure); surveys } \\
\text { (sensitivity); and index designed } \\
\text { with both aforementioned surveys } \\
\text { and interviews to experts } \\
\text { (adaptive capacity). }\end{array}$ & $\begin{array}{l}\text {-Exposure (model derived from six ocean } \\
\text { climate variables: sea surface temperature, } \\
\text { photosynthetically active radiation, } \\
\text { ultraviolet radiation, chlorophyll, surface } \\
\text { currents, and wind velocity). } \\
\text {-Sensitivity (level of dependence of fisheries } \\
\text { by surveys about economic } \\
\text { activity occupation). } \\
\text {-Adaptive capacity (what could impact the } \\
\text { number of fish in the sea, capacity to } \\
\text { respond, occupational mobility, } \\
\text { occupational multiplicity, social capital, } \\
\text { material assets related to style of life } \\
\text { indicator, technology, infrastructure). }\end{array}$ \\
\hline
\end{tabular}

\begin{tabular}{|c|c|c|c|}
\hline $\begin{array}{l}\text { Small island in the } \\
\text { South Pacific [24] }\end{array}$ & $\begin{array}{l}\text { Perception of } \\
\text { vulnerability to climate } \\
\text { change in island } \\
\text { destinations. }\end{array}$ & $\begin{array}{l}\text { Semi-structured online } \\
\text { questionnaire to potential travellers } \\
\text { and the public's information from } \\
\text { TV, print media, the Internet and } \\
\text { radio. Perceived likelihood, } \\
\text { perceived risks and implications of } \\
\text { these perceptions for potential } \\
\text { travel to this destination } \\
\text { are analyzed. }\end{array}$ & $\begin{array}{l}\text { Climate change impacts on tourist market } \\
\text { will depend on tourists' perception about } \\
\text { risk and vulnerability. Vulnerability is } \\
\text { defined as the likelihood of perceived (by } \\
\text { the public) and projected (by scientists) } \\
\text { impacts occurring. }\end{array}$ \\
\hline Caribbean coast [33] & $\begin{array}{l}\text { Vulnerability of } \\
\text { Caribbean coastal } \\
\text { tourism to sea level rise. }\end{array}$ & $\begin{array}{l}\text { Geo-referenced database of } 906 \\
\text { major coastal resort properties. } \\
\text { Flooding projections are calculated } \\
\text { for a sea level rise of } 1 \text { meter. }\end{array}$ & $\begin{array}{l}\text { Potential inundation impacts associated } \\
\text { with sea level rise. Geophysical conditions } \\
\text { are the main determinants of vulnerability. }\end{array}$ \\
\hline Fiji Islands [21] & $\begin{array}{l}\text { Vulnerability of coastal } \\
\text { destinations to } \\
\text { climate change. }\end{array}$ & $\begin{array}{l}\text { Identification of two key vulnerable } \\
\text { sub-systems (beach-cyclone and } \\
\text { snorkeling-coral bleaching) } \\
\text { analyzed by the Vulnerability } \\
\text { Scoping Diagram. (See Table 1). }\end{array}$ & $\begin{array}{l}\text {-Beach-cyclone subsystem: exposure } \\
\text { (infrastructure, local population, tourist } \\
\text { population, cyclone risk); sensitivity } \\
\text { (characteristics of beach-shore, } \\
\text { infrastructure conditions, tourists' } \\
\text { perceptions); adaptive capacity } \\
\text { (institutional support, access to financing; } \\
\text { management capacity) } \\
\text {-Snorkeling-coral bleaching subsystem: } \\
\text { exposure (storms, ocean conditions, reef); } \\
\text { sensitivity (reef, tourists); adaptive capacity } \\
\text { (managerial, technological, } \\
\text { institutional support). }\end{array}$ \\
\hline $\begin{array}{l}\text { Small islands in } \\
\text { general [34] }\end{array}$ & $\begin{array}{l}\text { Implications of } \\
\text { conceptualization of } \\
\text { small island states as } \\
\text { environmentally } \\
\text { vulnerable and } \\
\text { economically dependent. }\end{array}$ & $\begin{array}{l}\text { This study highlights the } \\
\text { importance of value judgments in } \\
\text { determining the degree of } \\
\text { vulnerability, insofar as it conditions } \\
\text { the identification of positive } \\
\text { attributes or forces for change and } \\
\text { improvement of certain areas. }\end{array}$ & $\begin{array}{l}\text { Narrow and frequently negative } \\
\text { conceptualizations of small island states as } \\
\text { environmentally vulnerable and } \\
\text { economically dependent are problematic } \\
\text { for the development of sustainable tourism } \\
\text { and economic development in general. } \\
\text { Vulnerability is seen as a social construction, } \\
\text { small islands are vulnerable because they } \\
\text { are conceptualized as vulnerable. }\end{array}$ \\
\hline
\end{tabular}

This paper considers contextual sociopolitical features to be key determinants of vulnerability. According with the contextual framework of vulnerability, which contrasts with the outcome vulnerability as Füssel [35] and O'Brien and Wolf [25] explain, this approach is based on the internal characteristics of the vulnerable subject, namely, the social, political and economic conditions that determine its exposure, its sensitivity and adaptive capacity. It matches with one of the three lines of thought identified by Eakin and Luers [36] regarding vulnerability assessments. Concretely, it matches with the line of political economy or political ecology as a response to the overemphasis on natural issues in risk-hazard research. It focuses on "why particular populations are vulnerable, how they are vulnerable, and, importantly, who precisely is vulnerable".

Two territories with the same physical conditions and threatened by climate change in the same way will differ in vulnerability because they may or may not implement different strategies. Policies determine the competitiveness, sustainability and development of tourism activity and the distribution of costs and benefits among direct and indirect stakeholders. Thus, this paper is 
also in line with Füssel and Klein [37], who highlight the move away from the assessment of the biophysical impacts of climate change associated with mitigation policies towards an analysis that focuses predominantly on evaluating strategies.

In short, the objectives of this paper are as follows: (i) to discuss why coastal destinations are vulnerable to climate change; (ii) to discover why decision-making and policies determine their vulnerability; and (iii) to propose a framework to assess vulnerability considering the importance of public policies. This research aims to provide an innovative theoretical framework applicable to coastal tourism destinations. This framework will structure vulnerability research and will generate useful information to improve policies and decision-making to deal with climate change in coastal destinations and to promote tourism sustainability.

In Section 2, we build up a definition of vulnerability taking into account climate impacts at coastal destinations. In Section 3, we explain the linkages between vulnerability and both policymaking and decision-making. In Section 4, we discuss policy analysis methods for assessing vulnerability. Finally, we summarize our conclusions in Section 5.

\section{Defining the Vulnerability of Coastal Destinations to Climate Change}

Definitions of vulnerability need to become narrower to cover specific research purposes so as to improve operability [28]. We identify three causes of vulnerability linked to climate change: direct negative impacts produced by climate change, indirect negative impacts produced by climate change and associated with both global warming effects and adaptation and mitigation strategies, and other negative socioeconomic impacts intensified by climate change that also condition the vulnerability of destinations.

In Figure 1, we establish these cause-effect relationships in coastal destinations in accordance with scientific reports $[10,11,38,39]$. These relationships will differ in each destination due to its exposure, sensitivity and adaptation and mitigation capacity.

Climate change is mostly due to socioeconomic drivers, including emissions of greenhouse gases (GHG), and its main consequence is global warming. However, these drivers also influence external stressors that intensify the secondary effects of climate change that are due to global warming. Significant consequences of global warming in coastal destinations include increased energy consumption for cooling purposes, higher prices due to a greater demand for water for cooling and recreation purposes, more frequent, more intense droughts [40], a greater need for insurance due to more frequent, more intense extreme events [41], the proliferation of organisms, illnesses and insects, and rises in sea level and ocean acidification, which together with global warming leads to coral bleaching and species migration.

These direct impacts of climate change are connected with three main indirect impacts on destinations: higher prices, a greater perception of risk among potential tourists, and a reduction in the quality of natural resources. The first of these mainly concerns energy and water consumption [42] and a greater need for insurance. The second involves more intense extreme meteorological events, such as flooding [33], hurricanes, tornados [43] or heat waves [44]; and an increase in organisms, insects and illnesses that may disturb tourists, e.g., jellyfish [45]. The third is related to the deterioration of the sea, reefs [46,47], beaches and landscapes [48]; land erosion and land loss; salinization, as well as the increase in climate discomfort for tourists [49]. 


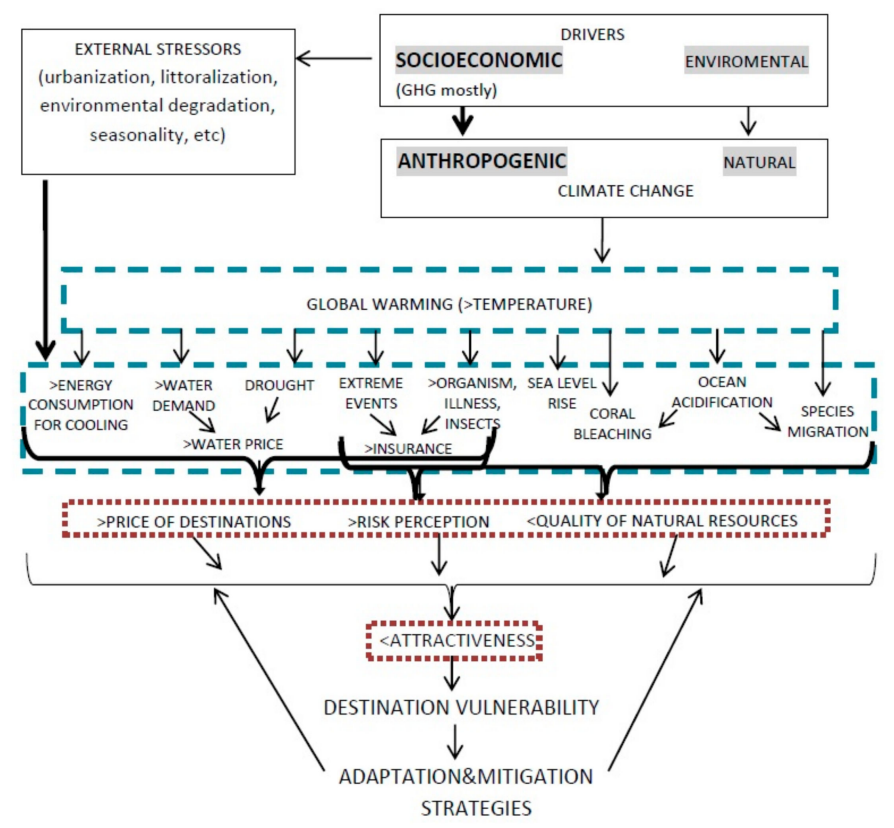

Intensification $\longrightarrow$

Direct impact of climate change at coastal destination $-=$

Indirect impact of climate change at coastal destination . .......

Figure 1. Framework of vulnerability of coastal destinations to climate change.

All of this reduces the attractiveness of destinations, which are therefore vulnerable to climate change and require adaptation and mitigation strategies. Adaptation strategies are designed according to local stressors and produce visible effects locally. Mitigation is a result of global thinking and, while reducing climate change on a global level, might also generate outputs locally [50]. Thus, strategies can modify tourists' preferences and consequently affect a destination's vulnerability [51]. Examples include measures affecting the cost of accommodation (e.g., energy costs for air conditioning due to adaptation) and travel (e.g., taxes on air travel due to mitigation) or reducing the quality of natural resources (e.g., the artificialization of beaches to combat rises in sea level [52]). We summarize this idea as follows:

$$
\begin{aligned}
& >\mathrm{P}+>\mathrm{R}+<\mathrm{Q}=<\mathrm{A} \\
& <\mathrm{A} \pm(\mathrm{AS}+\mathrm{MS})=\mathrm{V}
\end{aligned}
$$

where $\mathrm{P}$ is the prices in destinations, $\mathrm{R}$ is the tourists' risk perception, $\mathrm{Q}$ is the quality of natural resources, A is the attractiveness of the destination, AS is adaptation strategies, MS is mitigation strategies and $\mathrm{V}$ is vulnerability.

Therefore, the higher are the prices and the tourists' risk perception, and the more extensive is the degradation of natural resources, the lower the appeal of the coastal destination will be. However, the reduced attractiveness of the coastal destination combined with the results-both positive and negative - of the adaptation and mitigation strategies determine the level of vulnerability and therefore the sustainability of the coastal destination. Thus, we define vulnerability to climate change in destinations as the result of the reduction in the destination's attractiveness caused by climate change, combined with the consequences of adaptation and mitigation strategies.

For a more in-depth consideration of the direct and indirect effects of climate change in coastal destinations, Tables 3 and 4 contain examples of cause-effect relationships among climate change, socioeconomic stressors and the implications for coastal tourism taken into account in the IPCC's last report [5]. 
Table 3. Climate change effects in connection with tourism. Socioeconomic stressors and negative impacts on coastal tourism.

\begin{tabular}{|c|c|c|c|c|c|c|c|c|c|}
\hline & & $\begin{array}{l}\text { Temperature } \\
\text { Increase }\end{array}$ & $\begin{array}{c}\text { Sea Level } \\
\text { Rise }\end{array}$ & $\begin{array}{l}\text { Extreme } \\
\text { Events }\end{array}$ & $\begin{array}{c}\text { >Organism, } \\
\text { Illness, Insects }\end{array}$ & $\begin{array}{c}\text { Ocean } \\
\text { Acidification }\end{array}$ & $\begin{array}{c}\text { Coral } \\
\text { Bleaching }\end{array}$ & $\begin{array}{c}\text { Species } \\
\text { Migration }\end{array}$ & Drought \\
\hline \multirow{7}{*}{$\begin{array}{l}\text { Intensification by } \\
\text { socioeconomic } \\
\text { stressors }\end{array}$} & Mass tourism & & & & $\mathrm{x}$ & $\mathrm{x}$ & & $\mathrm{x}$ & $\mathrm{x}$ \\
\hline & Seasonality & & & $\mathrm{x}$ & & $x$ & & $x$ & $x$ \\
\hline & Littoralization & & $x$ & & & $x$ & & $x$ & \\
\hline & Urbanization & & $x$ & & & $x$ & & $x$ & \\
\hline & Economic development & $\mathrm{x}$ & $\mathrm{x}$ & & & $\mathrm{x}$ & & $x$ & $\mathrm{x}$ \\
\hline & GHG emissions & $\mathrm{x}$ & $\mathrm{x}$ & $\mathrm{x}$ & $\mathrm{x}$ & $x$ & $\mathrm{x}$ & & \\
\hline & Deficient planning & & & & $x$ & $x$ & & $x$ & \\
\hline \multirow{9}{*}{$\begin{array}{l}\text { Negative impacts } \\
\text { on sun sand and } \\
\text { sea tourism }\end{array}$} & $>$ Price of destinations & $\mathrm{x}$ & & $\mathrm{x}$ & $X$ & & & & $\mathrm{x}$ \\
\hline & More expensive accommodation & $\mathrm{x}$ & & & & & & & $\mathrm{x}$ \\
\hline & $\begin{array}{l}\text { More expensive travel } \\
\text { More expensive insurance }\end{array}$ & & & $\mathrm{x}$ & $\mathrm{x}$ & & & & \\
\hline & $<$ Quality of natural resources & $\mathrm{x}$ & $\mathrm{x}$ & $\hat{x}$ & & $\mathrm{x}$ & $\mathrm{x}$ & $\mathrm{x}$ & $\mathrm{x}$ \\
\hline & Decline in landscape quality & & $x$ & $x$ & & $x$ & $x$ & $x$ & $x$ \\
\hline & Uncomfortable climate & $\mathrm{x}$ & & $\mathrm{x}$ & & & & & $x$ \\
\hline & $<$ Interest for diving & & & & & $x$ & $\mathrm{x}$ & $x$ & \\
\hline & $>$ Risk perception & $\mathrm{X}$ & $\mathrm{x}$ & $\mathrm{x}$ & $\mathrm{X}$ & & & & $\mathrm{X}$ \\
\hline & $<$ Attractiveness of destination & $\mathrm{X}$ & $\mathrm{x}$ & $\mathrm{X}$ & $\mathrm{X}$ & $\mathrm{x}$ & $\mathrm{x}$ & $\mathrm{x}$ & $\mathrm{x}$ \\
\hline
\end{tabular}


Table 4. Examples of indirect climate change impacts as a consequence of mitigation and adaptation strategies.

\begin{tabular}{|c|c|c|c|c|c|c|c|}
\hline & & $\begin{array}{l}>\text { Energy } \\
\text { Consumption for } \\
\text { Cooling }\end{array}$ & $\begin{array}{c}>\text { Water Price } \\
\text { Because of } \\
\text { Scarcity }\end{array}$ & $\begin{array}{c}>\text { Water Consumption } \\
\text { for Recreation or } \\
\text { Tourists Comfort }\end{array}$ & $\begin{array}{l}\text { Artificialization } \\
\text { of Beaches Due to } \\
\text { Sea Level Rise }\end{array}$ & $\begin{array}{l}\text { Taxes to Reduce } \\
\text { GHG Emissions }\end{array}$ & $\begin{array}{l}\text { Pest Fumigation } \\
\text { or Insect } \\
\text { Repellent Needed }\end{array}$ \\
\hline \multirow{8}{*}{ Climatic driver } & Temperature Increase & $\mathrm{x}$ & $\mathrm{x}$ & $\mathrm{x}$ & & $\mathrm{x}$ & \multirow{8}{*}{$x$} \\
\hline & Sea Level Rise & & & & $\mathrm{x}$ & & \\
\hline & Extreme events & $\mathrm{x}$ & $\mathrm{x}$ & $\mathrm{x}$ & $x$ & & \\
\hline & $>$ Organism, illness, insects & & & & & & \\
\hline & Ocean acidification & & & & & $\mathrm{x}$ & \\
\hline & Coral bleaching & & & & & $\mathrm{x}$ & \\
\hline & Species migration & & & & & & \\
\hline & Drought & & $\mathrm{x}$ & & & & \\
\hline \multirow{10}{*}{$\begin{array}{l}\text { Negative impacts on } \\
\text { sun sand and sea } \\
\text { tourism features }\end{array}$} & $>$ Price of destinations & $\mathrm{X}$ & $\mathrm{x}$ & $\mathrm{X}$ & & $\mathrm{x}$ & $\mathrm{x}$ \\
\hline & More expensive accommodation & $\mathrm{x}$ & $\mathrm{x}$ & $\mathrm{x}$ & & & $x$ \\
\hline & More expensive travel & & & & & $\mathrm{x}$ & \\
\hline & More expensive insurance & & & & & & $\mathrm{x}$ \\
\hline & $<$ Quality of natural resources & & $\mathrm{x}$ & & $\mathrm{x}$ & & $\mathrm{x}$ \\
\hline & Decline in landscape quality & & & & $x$ & & \\
\hline & Uncomfortable climate & & $\mathrm{x}$ & & & & \\
\hline & $<$ Interest for diving & & & & $\mathrm{x}$ & & \\
\hline & >Risk perception & & & & & & $\mathbf{x}$ \\
\hline & $<$ Attractiveness of destination & $\mathrm{x}$ & $\mathrm{x}$ & $\mathrm{x}$ & $\mathrm{x}$ & $\mathrm{x}$ & $\mathrm{x}$ \\
\hline
\end{tabular}




\section{Linking Vulnerability with Policymaking and Decision-Making to Build an Analytical Framework}

We link this definition of vulnerability with the policymaking process. Phases of policymaking processes are settled and named in different ways (e.g., [53-55]). However, a common general sequence can be established. We relate the stages of vulnerability and policymaking in Figure 2 and highlight the interaction in two phases: in the policy formulation and decision-making, and in the final step of implementation. Although we acknowledge the success of strategy implementation as being key for reducing vulnerability, we focus on the formulation phase not only because it conditions implementation, but also because we want to point to the importance of ideas, values, risk perception and public decisions as determinants of vulnerability.

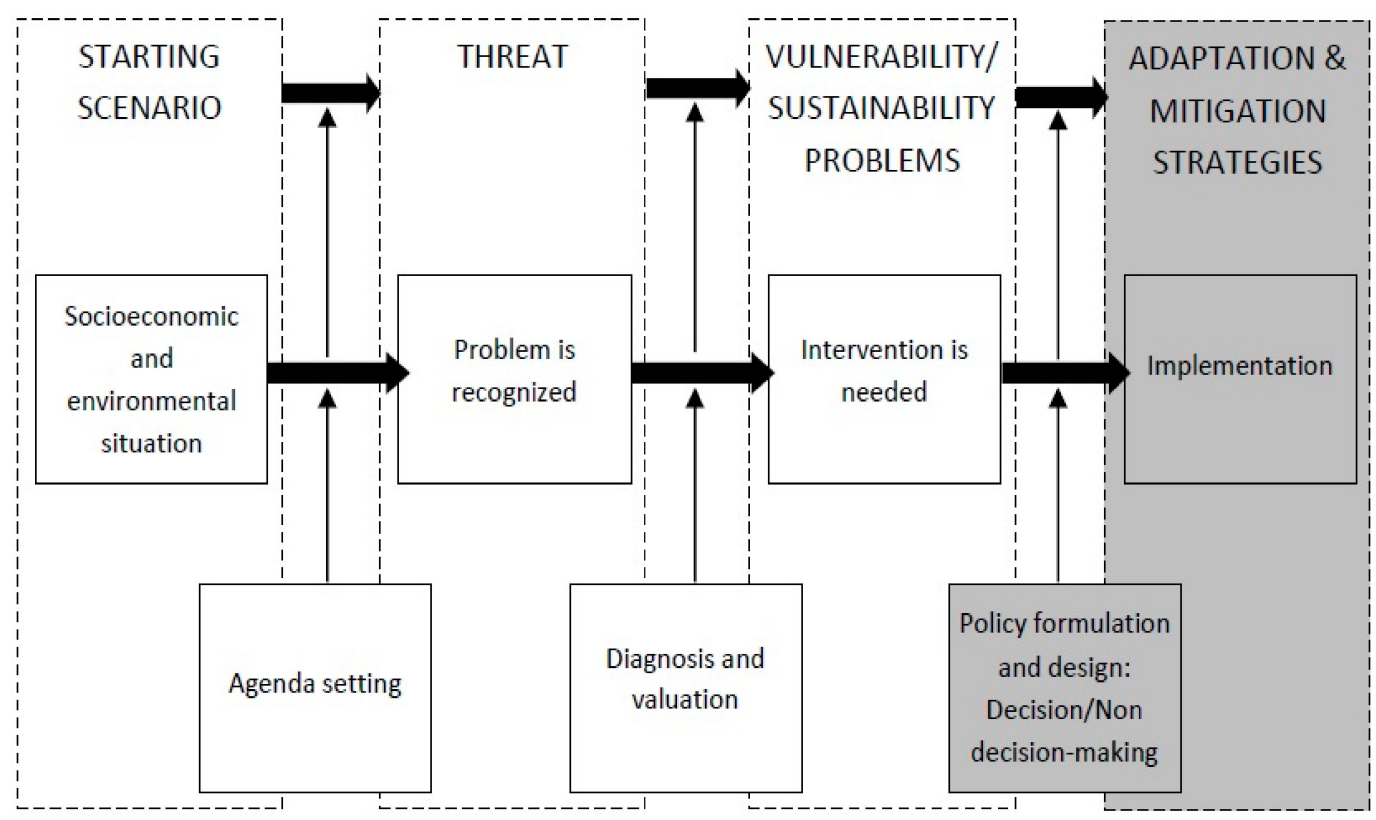

Figure 2. Vulnerability and the policy-making processes.

Decision-making has been studied from different disciplines and using different approaches [56]. The pioneer economists who defended rational choice were countered by authors who adopted a broader scope because it is not possible to justify decisions on rationality alone [57]. For example, decision-makers are not able to manage all available information [58,59], innovation is limited in organizations [60], power group satisfaction prevails over minorities $[61,62]$ and there are cognitive biases that distort rationality [63].

From a contextual perspective, therefore, we consider policy formulation and decision-making as outcomes of the complexity of the context [64]. The convergence of multiple interacting factors, actors, resources, institutions, ideas, information, etc. in a specific situation at a specific time leads to specific decisions, strategies and policies [65]. Vulnerability is considered a product of the destination context, too. If both vulnerability and policies are determined by context, then vulnerability can be assessed using policy analysis techniques that explain contextual characteristics.

We identify five components that have an effect on the degree of vulnerability, three of which also lead to decision and non-decision making. Using these five components, we build the Vulnerability Through Policies (VTP) framework that relates decision-making and vulnerability (Figure 3). The VTP framework makes it easier to adapt the vulnerability concept to each study and objective and facilitates the selection of indicators. 


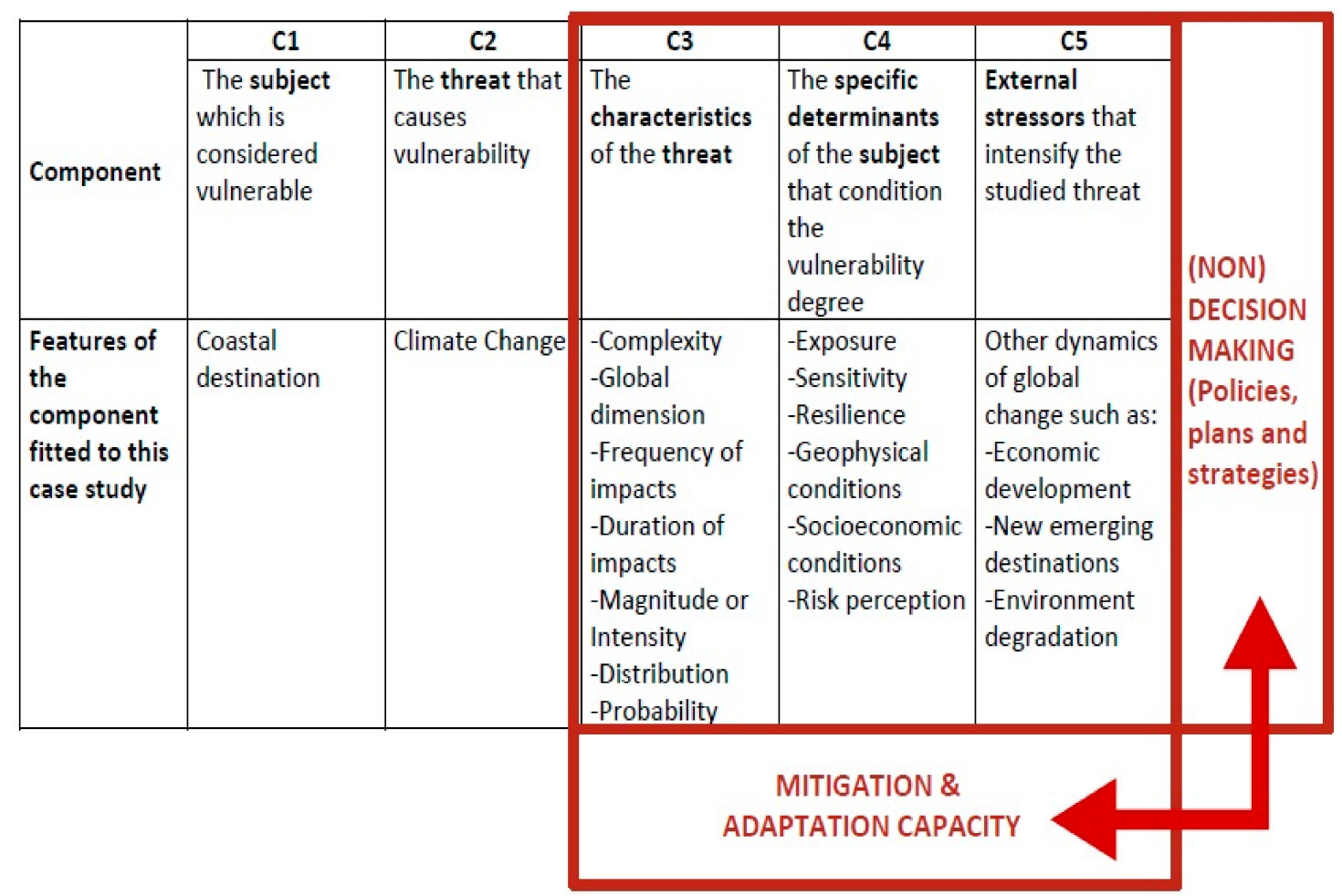

Figure 3. Vulnerability through Policies (VTP) framework applied to coastal destinations and climate change.

This framework satisfies the requirements and meets the challenges stated above. It enables place-based assessment but is aware of external stressors on a wider scale (C5). It incorporates the most cited determinants of vulnerability — sensitivity, exposure and resilience (C4) - and other concepts such as mitigation and adaptive capacity. The prospective scope is included by means of features such as probability (C3). It encompasses risk perception, which implies the involvement of stakeholders (C4). It also combines natural and human systems (C4) and integrates numerous indicators, components and linkages, thus incorporating all the complexity of vulnerability. Moreover, the VTP framework can be applied to different analytical-purpose case studies ( $\mathrm{C} 1$ and $\mathrm{C} 2$ ).

If we assume that vulnerability depends on the five components mentioned above, the last three components (C3, C4 and C5) determine mitigation and adaptive capacities. Decision-making relevance conditions both of these. However, decision-making includes non-decisions [66], and this is important in the case of climate change because, even in the most exposed destinations, actions are still limited.

At the same time, decision-making processes are influenced by factors related to vulnerability components, such as the information available on the characteristics of the threat, specific determinants for the subject (e.g., the training of decision-makers and economic, social and physical constrictions) and the dynamics and variables of global change, such as external stressors. The cause-effect relationship is therefore mutual. As Becken and Hay [67] explain, the strength of the enabling environment conditions the success of adaptation strategies in practices. What they called "enabling environment" regards the enforcement of institutions, policy frameworks, knowledge, decision's tools and methods, financing and technologies.

As an example, Tables 5-7 show some indicators that we can use in the case of coastal destinations and climate change. Each table includes one VTP framework component that determines mitigation and adaptive capacities, and all of them are consequently influenced by decision-making, while at the same time they are taken into account when making decisions (or at least they should be). 
Table 5. Threat characteristics (Component 3) influenced by decision-making and their influence on decision-making.

\begin{tabular}{ll}
\hline Complexity & \multicolumn{1}{c}{ Examples of Indicators } \\
\hline Global dimension & $\begin{array}{l}\text {-There are no concrete indicators but interaction between different } \\
\text { scales and indicators must be taken into account }\end{array}$ \\
\hline Frequency & -Global climatic trends (e.g., global warming) \\
& -Global climatic stressors (e.g., GHG emissions) \\
\hline Duration & -No. of extreme climatic events forecasted per period \\
\hline & -Time period \\
\hline Magnitude or Intensity & -Degrees/year for temperature \\
& -Meters/year for sea level rise \\
& -Meters/year for coastal erosion \\
& -Days/year for drought and heat waves \\
& -PH for ocean acidification \\
& -Percentage or surface of coral bleached \\
\hline \multirow{2}{*}{ Distribution } & -Surface \\
& -No. of people \\
\hline Probability & -No. of businesses affected \\
\hline
\end{tabular}

Table 6. Determinants specific to the subject that condition degree of vulnerability (Component 4) influenced by decision-making and their influence on decision-making.

\begin{tabular}{|c|c|c|}
\hline & \multicolumn{2}{|l|}{ Examples of Indicators } \\
\hline & Exposure & $\begin{array}{l}\text { Potentially affected: } \\
\text {-Population } \\
\text {-No. of businesses (e.g., hotels, diving, golf) } \\
\text {-No. or km of beaches } \\
\text {-Km of coastline urbanized } \\
\text {-Surface of reefs }\end{array}$ \\
\hline & Sensitivity & $\begin{array}{l}\text { Key resources for sun, sand and sea tourism: } \\
\text {-Coastline area already damaged or urbanized } \\
\text {-Water resources per capita } \\
\text {-Energy price/consumption per tourist in hotels } \\
\text {-Temperature and seasonality of tourism }\end{array}$ \\
\hline $\mathrm{C} 4$ & $\begin{array}{l}\text { Resilience or capacity } \\
\text { to cope }\end{array}$ & $\begin{array}{l}\text {-Both natural and human systems linked as the socioecological } \\
\text { system: geophysical conditions (natural system) and socioeconomic } \\
\text { conditions (human system) } \\
\text {-Risk perception } \\
\text {-Management capacity } \\
\text {-Institutional support }\end{array}$ \\
\hline & Geophysical conditions & $\begin{array}{l}\text { Key resources for sun, sand and sea tourism: } \\
\text {-Temperature } \\
\text {-Coastal characteristics (e.g., km, beaches, urbanization, adaptation } \\
\text { infrastructures, private or public) } \\
\text {-Marine ecosystem conservation }\end{array}$ \\
\hline & Socioeconomic conditions & $\begin{array}{l}\text {-Importance of tourism as economic sector (e.g., percent of Gross } \\
\text { Domestic Product; percent of employment) } \\
\text {-Gross Domestic Product } \\
\text {-Population (e.g., population growth, population per } \mathrm{km}^{2} \text {, population } \\
\text { depending on tourism) }\end{array}$ \\
\hline & Risk perception & -Stakeholders' and policymakers' perceptions, values and awareness \\
\hline
\end{tabular}


Table 7. External stressors that intensify the studied threat (Component 5) influenced by decision-making and their influence on decision-making.

\begin{tabular}{|c|c|c|}
\hline \multirow[b]{2}{*}{ C5 } & \multicolumn{2}{|r|}{ Examples of Indicators } \\
\hline & Dynamics of global change & $\begin{array}{l}\text {-Economic development (e.g., urbanization; land uses; GHG emissions) } \\
\text {-New emerging destinations } \\
\text {-Environmental degradation (e.g., mangroves/coral surface; residues per } \\
\text { visitor; seasonality) }\end{array}$ \\
\hline
\end{tabular}

\section{Discussing Policy Analysis Methods for Assessing the Vulnerability of Coastal Destinations to Climate Change}

The policy analysis discipline has evolved in line with the welfare state, which motivated the greater accountability of public expenditure. Positivist, institutional and rational approaches prevailed at the start, but, nowadays, the subjects, methods and scopes are wider and incorporate ideas, instruments, formal and non-formal organizations, networks and so on [68].

We see policy analysis as a holistic process of observation, measurement, interpretation and assessment that aims to improve our knowledge of complex public interventions from the setting of the agenda to the final results. Its conclusions are useful for decision-making, planning, public management and citizenship in general.

Complexity is an attribute of public interventions and has therefore also been a characteristic of policy analysis techniques since the beginning of the discipline [69]. Complexity is related to transversality, interdependence and fuzzy limits of responsibility, which are bigger in cross-sectoral policies such as tourism and climate change. Multiple actors and issues interact and influence policy-making, the definition of problems (whether or not they are included on the agenda), policy design, implementation and the quality of the final results.

The specific features of problems can increase the complexity of public action. Climate change policy involves various disciplines, uncertainty surrounding future impacts, rapid changes in information due to advances in research, long time frames for planning and lack of expertise at local level $[70,71]$. Tourism policy has to deal with cross-sectorality, long traditions in consolidated destinations that hamper the inclusion of new issues on the agenda, and the economic dependence of many regions. The peculiarities of tourism make research about public action more complicated [72-76], not only because tourism is becoming increasingly difficult to delimit, but also because the problems that have to be dealt with are becoming increasingly complex and globalized-for instance, climate change. Moreover, coastal zone management involves a wide range of dynamic and conflicting interests, actors and uses. Coastal management is expected to become even more complex due to, on the one hand, the reduction of beaches for recreation because of more intense coastal erosion linked to climate change [6,77] and, on the other hand, the growing of tourism fluxes [78].

The indicators for evaluating vulnerability must also be complex, forward-looking (since impacts are potential), available, reliable and comparable [28] between different cases. They need to prioritize the local scale while being aware of the nesting of scales [1,23,79]. All these requirements are met by the methods and sources proposed in Figure 4: (1) content analysis of policy documents; and (2) analysis of the perceptions and opinions of the stakeholders that influence decision-making. Combining both of these reinforces and validates the results.

Policy contents have other advantages when considered as indicators. According to Velasco-González [80], policy documents contain numerous ideas and values that drive and justify actions. They are based-or at least should be-on the characteristics of socioecological systems, the availability of resources, potential impacts, etc. They show the perceptions of policymakers regarding context and risk: the existence and magnitude of problems and their potential solutions. They should also make the objectives, tools and resources clear.

Looking in more detail at the methodology we propose, although content analysis methods are mostly qualitative, they do bring together both quantitative and qualitative techniques, mostly 
by using interpretative category classification and quantifying certain issues in the text. Computer software is also available to support it [81-83]. It is possible to request a quantification of key words or subjects to note their presence or absence in the various parts of the document (objectives, diagnosis, measures, etc.) and examine the inclusion of problems and their magnitude. Some studies have quantified subjects so as to determine the relevance of issues, for example, the research carried out by Scott et al. [84] into tourism in the IPCC reports and by Santos-Lacueva et al. [85] into environmental sustainability in tourism plans.

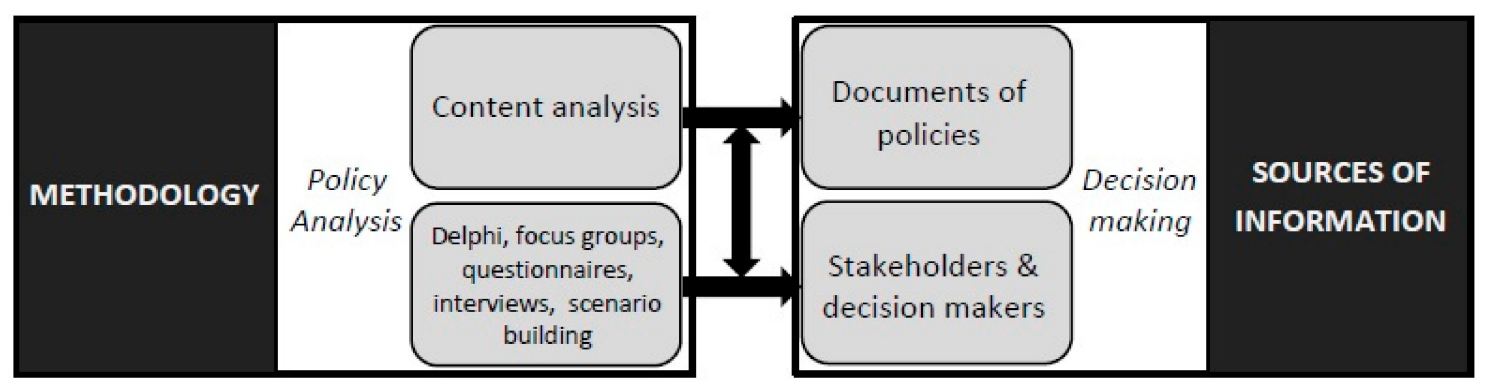

Figure 4. Policy analysis methods and sources for assessing vulnerability.

It is also possible to seek a critical interpretation of the contents in order to overcome descriptive approaches that hinder advances in the field of tourism policies [86]. We need to understand why issues are present or absent, why they are or are not urgent, and why, even though they are in documents, they might not be translated into actions. In line with Fisher and Gottwies [87], we intend to focus on discourses, arguments and conceptualization. Despite the fact that some papers have aimed to analyze the conceptualization [88] and discourses of tourism policies [89], this is not common in the field of tourism. Nevertheless, discourse analysis has a long trajectory in the environmental policy domain [90]. Therefore, by analyzing meanings and arguments, we can observe how climate change is conceived from a tourism perspective (e.g., is it a threat or an opportunity?) and the opposite perspective (e.g., does tourism intensify or suffer from climate change?), and find out what the most urgent risks are (e.g., beach erosion, temperature increase, water scarcity, etc.), which might not match with the scientific perspective. These values and ideas reflected on policies will condition destinations' vulnerability to climate change.

We also propose to carry out the research inductively. Dominant trends, significant themes and general conclusions emerge by analyzing documents individually [91]. The operating mode is therefore predominantly top-down, considering documents produced at higher decision-making levels first.

We aim to complement the analysis of policy documents considering stakeholders' perceptions and opinions that influence decision-making. Their perceptions of risk are critical when it comes to including the issue on the agenda or deciding how to respond. There are several techniques of social science research applicable to reach this purpose of information, such as Delphi, focus groups, questionnaires, interviews, or scenario building. The choice will depend on the peculiarities of the study case, economic and time resources, and the will of stakeholders to participate. There are examples of using interviews and questionnaires to understand the policy problems of climate change related to tourism $[92,93]$. We can also recognize the power relationships and discourses between individual actors, organizations and lobbies that explain why certain actions are only designed or both designed and implemented and why other actions are not contemplated by policy-makers [94,95].

Thus, we can identify the key actors that lead adaptation and mitigation in destinations along with those that should be engaged in improving the results of these strategies. We can also find out the obstacles to successful adaptation and mitigation in destinations that need to be overcome, such as coordination between different levels of government, tourism and climate change arenas or public and private dimensions, awareness, and human, technical and economic resources [94]. 
Other authors have studied the participation of tourism stakeholders in the policymaking process of climate policies to understand the role of the tourism sector coping with climate change [96]. There is also research through deep interviews to investigate policymakers' perceptions about the relationship between tourism and climate change or about climate change policy needs in tourism [97]. Interviews with policymakers have been used as well to study how institutional and government changes in climate change discourses might transform social behavior and, consequently increase resilience to climate change [96].

Meanwhile, a comparison between several destinations may be useful in reflecting best practices or helping us learn from the way both similar and dissimilar problems are dealt with. The VTP framework together with the proposed methods and indicators enables comparison between different cases and between specific aspects, such as differences at decision levels or from an evolutionary perspective.

\section{Conclusions}

This paper assumes the relevance of considering global change to manage destinations in a sustainable way. In this context, we identified two main academic challenges that can contribute to improving coastal destination management to ensure sustainability in new climate scenarios: (1) to provide a framework for research dealing with the complexities of tourism and global dynamics while improving the functionality and utility of overarching concepts that are sometimes ambiguous and inoperative, such as vulnerability [1,2]; and (2) to overcome the gap in tourism policy research in order to obtain useful information and effective planning tools [72,86,98].

As a result, we suggest an innovative framework to assess the vulnerability of coastal destinations to climate change from the perspective of public policies. Indeed, we contribute with the twofold challenge mentioned above. On the one hand, coastal tourism is one of the most vulnerable subsectors [39] and information related to climate change is especially scarce at regional and local levels [70,71]. Then, the proposed framework facilitates and structures research on vulnerability at local scale $[1,23,28,29,79]$ in order to increase knowledge and information to cope with climate change and coastal tourism. On the other hand, the focus of the framework on public policies promotes the production of knowledge on tourism policy. Thus, in the field of tourism policy, we contribute to the strengthening of theoretical frameworks able to capture complexity and be used in different contexts [85,94], surpassing research that mainly focuses on case studies, timeline studies and examples of good practices or political recommendations $[86,98]$.

As a key outcome of this research, we show the close relationship between public policies and vulnerability of destinations. Beyond the physical characteristics of destinations and the direct impacts of climate change, public policies are a key determinant of the vulnerability of destinations. Some study cases have already pointed out the weakness of policy frameworks as a barrier to deal with climate change $[67,99]$, as well as the lack of integration between tourism and climate change policies [96] or the lack of coordination between public administrations and between the public and the private sector $[94,99]$. Then, two destinations with the same physical features and suffering the same direct impacts of climate change will differ in vulnerability according to policy-making and the success of strategies. It can be specifically observed from the policy-formulation and implementation stages.

Then, we propose to go beyond quantitative physical assessments of vulnerability that describe reality $[20,26]$. We also encourage to incorporate multidisciplinary approaches and to enhance the social science perspective [21-25] to produce applicable outputs capable of improving this reality.

We then advocate the usefulness of the policy analysis approach to evaluate the vulnerability of destinations. Complex, multiple, dynamic and fuzzy attributes are characteristic not only of vulnerability but also of all the items that frame this research. The method (policy analysis) and indicators (policy contents and stakeholder perceptions) are both justified because they share these attributes [69], with vulnerability as a variable [1], climate change as a phenomenon [63], the coastal destination as a territorial system, and both tourism activity and tourism policy [64]. 
Further research is being carried out empirically to prove the proposal. Empirical research will determine concrete factors that condition public policies in different contexts, and consequently we will detail sociopolitical specificities that condition vulnerability to climate change in coastal destinations.

Acknowledgments: This research has been funded by the Spanish Ministry of Economy and Competitiveness (GLOBALTUR project CSO2011-23004 and MOVETUR project CSO2014-51785-R).

Author Contributions: Three authors contributed to this research. Raquel Santos-Lacueva acted as first author throughout the study idea, manuscript drafting and writing. Salvador Anton Clavé and Òscar Saladié critically supervised and revised the whole work developed. All authors contributed to the scientific content of the paper, read and approved the final manuscript.

Conflicts of Interest: The authors declare no conflict of interest.

\section{References}

1. Polsky, C.; Neff, R.; Yarnal, B. Building comparable global change vulnerability assessments: The vulnerability scoping diagram. Glob. Environ. Chang. 2007, 17, 472-485. [CrossRef]

2. Thywissen, K. Components of Risk. A Comparative Glossary; United Nations University Institute for Environment and Human Security: Bonn, Germany, 2006; ISBN 398-1-05-820-8.

3. Fritzsche, K.; Schneiderbauer, S.; Bubeck, P.; Kienberger, S.; Buth, M; Zebisch, M.; Kahlenborn, W. The Vulnerability Sourcebook: Concept and Guidelines for Standardised Vulnerability Assessments; Deutsche Gesellschaft für: Bonn, Germany, 2014.

4. Intergovernmental Panel on Climate Change (IPCC). Annex II: Glossary. In Climate Change 2014: Synthesis Report; Contribution of Working Groups I, II and III to the Fifth Assessment Report of the Intergovernmental Panel on Climate Change; IPCC: Geneva, Switzerland, 2014; pp. 117-130.

5. Intergovernmental Panel on Climate Change (IPCC). Impacts, Adaptation and Vulnerability; Contribution of Working Group II to the Fourth Assessment Report of the Intergovernmental Panel on Climate Change; Cambridge University Press: Cambridge, UK, 2007.

6. Jones, A.; Phillips, M. Disappearing Destinations: Climate Change and Future Challenges for Coastal Tourism; Cabi: Oxfordshire, UK, 2011; ISBN 978-1-84-593548-1.

7. Gómez Martín, B. Weather, climate and tourism a geographical perspective. Ann. Tour. Res. 2005, 32, 571-591. [CrossRef]

8. Scott, D.; McBoyle, G. Using a "tourism climate index" to examine the implications of climate change for climate as a tourism resource. In Proceedings of the First International Workshop on Climate, Tourism and Recreation, Neos Marmaras, Greece, 5-10 October 2001; Matzarakis, A., de Freitas, C.R., Eds.; International Society of Biometeorology: Halkidiki, Greece, 2001; pp. 69-88.

9. Williams, P.W.; Ponsford, I.F. Confronting tourism's environmental paradox: Transitioning for sustainable tourism. Futures 2009, 49, 396-404. [CrossRef]

10. Simpson, M.C.; Gössling, S.; Scott, D.; Hall, C.M.; Gladin, E. Climate Change Adaptation and Mitigation in the Tourism Sector: Frameworks, Tools and Practices; UNEP, University of Oxford, UNWTO, WMO: Paris, France, 2008; ISBN 978-9-28-072921-5.

11. UNWTO; UNEP. Climate Change and Tourism: Responding to Global Challenges; UNWTO: Madrid, Spain, 2008; ISBN 978-9-28-441234-1.

12. ETC CCA. Methods for Assessing Coastal Vulnerability to Climate Change; European Environmental Agency: Bologna, Italy, 2011.

13. Bosom, E.; Jiménez, J.A. Probabilistic coastal vulnerability assessment to storms at regional scale-Application to Catalan beaches (NW Mediterranean). Nat. Hazards Earth Syst. Sci. 2011, 11, 475-484. [CrossRef]

14. Gornitz, V.M.; White, T.W. A Coastal Hazards Database for the U.S. East Coast; Oak Ridge National Laboratory: Oak Ridge, TN, USA, 1992.

15. Deduce Consortium. Indicators Guidelines to Adopt an Indicators-Based Approach to Evaluate Coastal Sustainable Development; Department of the Environment and Housing, Government of Catalonia: Barcelona, Spain, 2007.

16. Marcomini, A.; Suter, G.W.; Crito, A. (Eds.) Decision Support Systems for Risk Based Management of Contaminated Sites; Springer: New York, NY, USA, 2009; ISBN 978-0-38-709722-0. 
17. Hinkel, J.; Klein, R. Integrating knowledge to assess coastal vulnerability to sea-level rise: The development of the DIVA tool. Glob. Environ. Chang. 2010, 19, 384-395. [CrossRef]

18. Turner, B.L.; Kasperson, R.E.; Matson, P.A.; McCarthy, J.J.; Corell, R.W.; Christensen, L.; Schiller, A. A framework for vulnerability analysis in sustainability science. Proc. Natl. Acad. Sci. USA 2003, 100, 8074-8079. [CrossRef] [PubMed]

19. Adger, W.N. Vulnerability. Glob. Environ. Chang. 2006, 16, 268-281. [CrossRef]

20. Nicholls, R.J.; Wong, P.P.; Burkett, V.; Woodreoffe, C.D.; Hay, J. Climate change and coastal vulnerability assessment: Scenarios for integrated assessment. Sustain. Sci. 2008, 3, 89-102. [CrossRef]

21. Moreno, A.; Becken, S. A climate change vulnerability assessment methodology for coastal tourism. J. Sustain. Tour. 2009, 17, 473-488. [CrossRef]

22. Füssel, H.M. Vulnerability: A generally applicable conceptual framework for climate change research. Glob. Environ. Chang. 2007, 17, 155-167. [CrossRef]

23. Schröter, D.; Polsky, C.; Patt, A.G. Assessing vulnerabilities to the effects of global change: An eight step approach. Mitig. Adapt. Strateg. Glob. Chang. 2005, 10, 573-596. [CrossRef]

24. Huebner, A. Public perceptions of destination vulnerability to climate change and implications for long-haul travel decisions to small Island States. J. Sustain. Tour. 2012, 20, 939-951. [CrossRef]

25. O'Brien, K.L.; Wolf, J. A values-based approach to vulnerability and adaptation to climate change. Clim. Chang. 2010, 1, 232-242. [CrossRef]

26. Kelly, P.; Adger, W. Theory and practice in assessing vulnerability to climate change and facilitating adaptation. Clim. Chang. 2000, 47, 325-352. [CrossRef]

27. Brooks, N.; Neil Adger, W.; Mick Kelly, P. The determinants of vulnerability and adaptive capacity at the national level and the implications for adaptation. Glob. Environ. Chang. 2005, 15, 151-163. [CrossRef]

28. Hinkel, J.; Klein, R. Integrating knowledge for assessing coastal vulnerability to climate change. In Managing Coastal Vulnerability: An Integrated Approach; McFadden, I., Nicholls, R.J., Penning-Rowsell, E.C., Eds.; Elsvier Science: Amsterdam, The Netherlands, 2007; pp. 61-78.

29. Torresan, S.; Critto, A.; Dalla Valle, M.; Harvey, N.; Marcomini, A. Assessing coastal vulnerability to climate change: Comparing segmentation at global and regional scales. Sustain. Sci. 2008, 3, 45-65. [CrossRef]

30. Calgaro, E.; Lloyd, K.; Dominey-Howes, D. From vulnerability to transformation: A framework for assessing the vulnerability and resilience of tourism destinations. J. Sustain. Tour. 2014, 22, 341-360. [CrossRef]

31. Perch-Nielsen, S.L. The vulnerability of beach tourism to climate change-an index approach. Clim. Chang. 2010, 100, 579-606. [CrossRef]

32. Cinner, J.E.; Mc Clanahan, T.R.; Graham, N.A.J.; Daw, T.M.; Maina, J.; Stead, S.M.; Bodin, Ö. Vulnerability of coastal communities to key impacts of climate change on coral reef fisheries. Glob. Environ. Chang. 2012, 22, 12-20. [CrossRef]

33. Scott, D.; Simpson, M.C.; Sim, R. The vulnerability of Caribbean coastal tourism to scenarios of climate change related sea level rise. J. Sustain. Tour. 2012, 20, 883-898. [CrossRef]

34. Scheyvens, R.; Momsen, J. Tourism in small island states: From vulnerability to strengths. J. Sustain. Tour. 2008, 16, 491-510. [CrossRef]

35. Füssel, H.M. Review and quantitative analysis of indices of climate change exposure, adaptive capacity, sensitivity, and impacts. In Background Note to the World Development Report 2010; World Bank Group: Washington, DC, USA, 2009.

36. Eakin, H.; Luers, A.L. Assessing the vulnerability of social-environmental systems. Ann. Rev. Environ. Resour. 2006, 31, 365-394. [CrossRef]

37. Füssel, H.M.; Klein, R.J.T. Climate change vulnerability assessments: An evolution of conceptual thinking. Clim. Chang. 2006, 75, 301-329. [CrossRef]

38. Intergovernmental Panel on Climate Change (IPCC). Coastal systems and low-lying areas. In Climate Change 2014: Impacts, Adaptation, and Vulnerability. Part A: Global and Sectorial Aspects; Contribution of Working Group II to the Fifth Assessment Report of the Intergovernmental Panel on Climate Change; Cambridge University Press: Cambridge, UK, 2014; pp. 361-409.

39. Intergovernmental Panel on Climate Change (IPCC). Key economic sectors and services. In Climate Change 2014: Impacts, Adaptation, and Vulnerability. Part A: Global and Sectorial Aspects; Contribution of Working Group II to the Fifth Assessment Report of the Intergovernmental Panel on Climate Change; Cambridge University Press: Cambridge, UK, 2014; pp. 659-708. 
40. Kent, M.; Newnham, R.; Essex, S. Tourism and sustainable water supply in Mallorca: A geographical analysis. Appl. Geogr. 2002, 22, 351-374. [CrossRef]

41. Becken, S.; Hay, J. Insurance, climate change and tourism. In Tourism and Climate Change: Risks and Opportunities; Becken, S., Hay, J., Eds.; Chanel View Publications: Clevedon, UK, 2007; pp. 59-70; ISBN 978-1-84-541067-4.

42. Hein, L.; Metzger, M.J.; Moreno, A. Potential impacts of climate change on tourism; a case study for Spain. Curr. Opin. Environ. Sustain. 2009, 1, 170-178. [CrossRef]

43. Park, K.; Reisinger, Y. Differences in the perceived influence of natural disasters and travel risk on international travel. Tour. Geogr. 2010, 12,1-24. [CrossRef]

44. Gómez-Martín, M.B.; Armesto-López, X.A.; Martínez-Ibarra, E. The Spanish tourist sector facing extreme climate events: A case study of domestic tourism in the heat wave of 2003. Int. J. Biometeorol. 2014, 58, 781-797. [CrossRef] [PubMed]

45. Nunes, P.A.L.D.; Loureiro, M.L.; Piñol, L.; Sastre, S.; Voltaire, L.; Canepa, A. Analyzing beach recreationists' preferences for the reduction of jellyfish blooms: Economic results from a stated-choice experiment in Catalonia, Spain. PLoS ONE 2015, 10, 1-13. [CrossRef] [PubMed]

46. Brander, L.M.; Rehdanz, K.; Tol, R.S.J.; van Beukering, P.H.J. The economic impact of ocean acidification on coral reefs. Clim. Chang. Econ. 2012, 3, 1-29. [CrossRef]

47. Rodrigues, L.C.; van den Bergh, J.C.J.M.; Loureiro, M.L.; Nunes, P.A.L.D.; Rossi, S. The cost of Mediterranean Sea warming and acidification: A choice experiment among scuba divers at Medes Islands, Spain. Environ. Resour. Econ. 2016, 63, 289-311. [CrossRef]

48. Uyarra, M.C.; Côté, I.M.; Gill, J.A.; Tinch, R.R.T.; Viner, D.; Watkinson, A.R. Island-specific preferences of tourists for environmental features: Implications of climate change for tourism-dependent states. Environ. Conserv. 2005, 32, 11-19. [CrossRef]

49. Amelung, B.; Nicholls, S.; Viner, D. Implications of global climate change for tourism flows and seasonality. J. Travel Res. 2007, 45, 285-296. [CrossRef]

50. Scott, D.; Gössling, S.; Hall, C.M.; Peeters, P. Can tourism be part of the decarbonized global economy? The costs and risks of alternate carbon reduction policy pathways. J. Sustain. Tour. 2016, 24, 52-72. [CrossRef]

51. Barnett, J.; O’Neill, S. Maladaptation. Glob. Environ. Chang. 2010, 20, 211-213. [CrossRef]

52. Hamilton, J.M. Coastal landscape and the hedonic price of accommodation. Ecol. Econ. 2007, 62, 594-602. [CrossRef]

53. Lasswell, H. The Decision Process: Seven Categories of Functional Analysis; University of Maryland: College Park, MD, USA, 1956.

54. Jenkins, W. Policy Analysis: A Political and Organizational Perspective; Robertson: London, UK, 1978; ISBN 085-5-20-200-9.

55. Werner, J.; Wegrich, K. Theories of the Policy Cycle. In Handbook of Public Policy Analysis. Theory, Politics, and Methods; Fisher, F., Miller, G., Sidney, M., Eds.; Taylor \& Francis: Boca-Raton, FL, USA, 2007; pp. 43-62. ISBN 978-1-57-444561-9.

56. Parsons, W. Public Policy: An Introduction to the Theory and Practice of Policy Analysis; Edward Elgar: Cheltenham, UK, 1996; ISBN 978-1-85-278554-3.

57. Harguindéguy, J.B. Análisis de Políticas Públicas; Tecnos: Madrid, Spain, 2015; ISBN 843-0-96-743-5.

58. Simon, H. Administrative Behavior: A study of Decision-Making Processes in Administrative Organizations; The Free Press: New York, NY, USA, 1947; ISBN 978-0-68-483582-2.

59. Lindblom, C. Still Muddling, not yet through. Public Adm. Rev. 1979, 19, 517-526. [CrossRef]

60. Cohen, M.; March, J.; Olsen, J. A garbage can model of organizational choice. Adm. Sci. Q. 1972, 17, 1-25. [CrossRef]

61. Lindblom, C. Politics and Markets: The World's Political Economic Systems; Basic Books: New York, NY, USA, 1997; ISBN 978-0-46-505958-4.

62. Dahl, R. Dilemmas of Pluralist Democracy: Autonomy vs. Control; Yale University Press: New Haven, CT, USA, 1982; ISBN 978-0-30-017340-6.

63. Fischer, G.N. Les Concepts Fondamentaux de la Psychologie Sociale; Dunod: Paris, France, 1987; ISBN 978-2-76-060787-3.

64. Stevenson, N.; Airey, D.; Miller, G. Complexity theory and tourism policy research. Int. J. Tour. Policy 2009, 2, 206-220. [CrossRef] 
65. Sidney, M. Policy Formulation: Design and Tools. In Handbook of Public Policy Analysis. Theory, Politics, and Methods; Fisher, F., Miller, G., Sidney, M., Eds.; Taylor \& Francis: Boca Raton, FL, USA, 2007; pp. 79-87; ISBN 978-1-57-444561-9.

66. Bachrach, P.; Baratz, M. The two faces of power. Am. Polit. Sci. Rev. 1962, 56, 947-952. [CrossRef]

67. Becken, S.; Hay, J.E. Climate Change and Tourism: From Policy to Practice; Routledge: New York, NY, USA, 2012; ISBN 978-1-84-971475-4.

68. Fisher, F.; Miller, G.; Sidney, M. Handbook of Public Policy Analysis. Theory, Politics, and Methods; Taylor \& Francis: Boca Raton, FL, USA, 2007; ISBN 978-1-57-444561-9.

69. Rittel, H.V.J.; Webber, M.M. Dilemmas in a general theory of planning. Policy Sci. 1973, 4, 155-169. [CrossRef]

70. Tomkins, E.; Adger, N. Defining response capacity to enhance climate change strategy. Environ. Sci. Policy 2005, 9, 562-571. [CrossRef]

71. Burton, D.; Dredge, D. (Griffith University) Framing climate: Implications for local government policy response capacity. Personal Comunication, 2010.

72. Dredge, D.; Jenkins, J. Stories of Practice: Tourism Policy and Planning; Ashgate Publishing: Farnham, UK, 2011; ISBN 978-0-75-469949-1.

73. Elliott, J. Tourism: Politics and Public Sector Management; Routledge: London, UK, 1997; ISBN 020-3-41-613-9.

74. Hall, C.M. Tourism and Politics. Policy, Power and Place; Jhon Wiley \& Sons Ltd.: Chichester, UK, 1994; ISBN 047-1-94-919-1.

75. Hall, M.; Page, S. Tourism and recreation planning and policy. In The Geography of Tourism and Recreation: Environment, Place and Space; Hall, M., Page, S., Eds.; Routledge: London, UK, 2002; ISBN 041-5-25-081-1.

76. Kerr, W. Tourism Public Policy, and Strategic Management of Failure; Elsevier: Oxford, UK, 2003; ISBN 008-0-44-200-5.

77. Phillips, M.R.; Jones, A.R. Erosion and tourism infrastructure in the coastal zone: Problems, consequences and management. Tour. Manag. 2006, 27, 517-524. [CrossRef]

78. UNWTO. Tourism Highlights; UNWTO: Madrid, Spain, 2017; ISBN 978-9-28-441902-9.

79. Hinkel, J. Indicators of vulnerability and adaptive capacity: Towards a clarification of the science-policy interface. Glob. Environ. Chang. 2011, 21, 198-208. [CrossRef]

80. Velasco-González, M. Tourism policy: An autonomous policy arena. Cuad. Tur. 2011, 27, 1171-1174.

81. Kohlbacher, F. The use of qualitative content analysis in case study research. Forum Qual. Soc. Res. 2006, 7, 3-13.

82. Mayring, P. Qualitative content analysis. Forum Qual. Soc. Res. 2000, 1, 20.

83. Weber, R.P. Basic Content Analysis; Sage Publications: Thousand Oaks, CA, USA, 1990; ISBN 978-0-80-393863-2.

84. Scott, D.; Hall, C.M.; Gössling, S. A review of the IPCC Fith Assessment and implications for tourism sector climate resilience and decarbonization. J. Sustain. Tour. 2016, 14, 8-30. [CrossRef]

85. Santos-Lacueva, R.; Anton Clavé, S.; Saladié, O. Discontinuities and limitations of the most recent Spanish tourism plans related to the environmental sustainability of sun and sand tourism. Cuad. Tur. 2017, 40, 599-626.

86. Dredge, D.; Jamal, T. Progress in tourism planning and policy: A post-structural perspective on knowledge production. Tour. Manag. 2015, 51, 285-297. [CrossRef]

87. Fisher, F.; Gottwies, H. The Argumentative Turn Revised: Public Policy as a Communicative Practice; Duke University Press: Durham, UK, 2012; ISBN 978-0-82-235263-1.

88. Torres-Delgado, A.; López Palomeque, F. The growth and spread of the concept of sustainable tourism: The contribution of institutional initiatives on tourism policy. Tour. Manag. Perspect. 2012, 4, 1-10. [CrossRef]

89. Chaderopa, C. Legitimising transboundary conservation-development initiatives: A discourse analysis of policy-decision making and its implications for rural community participation. Int. J. Tour. Policy 2013, 5, 128-151. [CrossRef]

90. Hajer, M.; Versteeg, W. A decade of discourse analysis of environmental politics: Achievements, challenges, perspectives. J. Environ. Policy Plan. 2005, 7, 175-184. [CrossRef]

91. Thomas, D.R. A general inductive approach for analyzing qualitative evaluation data. Am. J. Eval. 2006, 27, 237-246. [CrossRef]

92. Dodds, R.; Kelman, I. How climate change is considered in sustainable tourism policies: A case of the Mediterranean islands of Malta and Mallorca. Tour. Rev. Int. 2008, 12, 57-70. [CrossRef]

93. Belle, N.; Bramwell, B. Climate Change and Small Island Tourism: Policy Maker and Industry Perspectives in Barbados. J. Travel Res. 2005, 44, 32-41. [CrossRef] 
94. Santos-Lacueva, R.; Saladié, Ò. Public action on tourism and climate change: The perceptions of stakeholders in the Riviera Maya (Mexico). PASOS 2016, 14, 611-630.

95. Tomkins, E. Planning for climate change in small islands: Insights from national hurricane preparedness in the Cayman Islands. Glob. Environ. Chang. 2005, 15, 139-149. [CrossRef]

96. Becken, S.; Clapcott, R. National tourism policy for climate change. J. Policy Res. Tour. Leis. Events 2011, 3, 1-17. [CrossRef]

97. Hambira, W.L.; Saarinen, J. Policy-makers' perceptions of the tourism-climate change nexus: Policy needs and constraints in Botswana. Dev. South. Afr. 2015, 32, 350-362. [CrossRef]

98. Jenkins, J.M.; Hall, C.M.; Mkno, M. Tourism and Public Policy. Contemporary Debates and Future Directions. In The Wiley Blackwell Companion to Tourism; Lew, A.A., Hall, M.C., Williams, A.M., Eds.; Jhon Wiley \& Sons Ltd.: Chichester, UK, 2014; pp. 542-555. ISBN 978-1-11-847448-8.

99. Dodds, R.; Graci, S. Canada's Tourism Industry-Mitigating the Effects of Climate Change: A Lot of Concern but Little Action. Tour. Hosp. Plan. Dev. 2009, 6, 39-51. [CrossRef]

(C) 2017 by the authors. Licensee MDPI, Basel, Switzerland. This article is an open access article distributed under the terms and conditions of the Creative Commons Attribution (CC BY) license (http:/ / creativecommons.org/licenses/by/4.0/). 